\title{
Housing Affordability Index: Real Estate Market and Housing Situations
}

\author{
Leopoldo Sdino ${ }^{1, a}$, Paola Castagnino $0^{1, b}$ \\ ${ }^{1}$ Politecnico di Milano, Via Ponzio 31, Milan, Italy \\ aeo.sdino@polimi.it, ${ }^{\mathrm{b}}$ paola.castagnino@polimi.it
}

\begin{abstract}
Keywords: Housing Affordability Index, Social Economy, Social Inclusion and Fighting Poverty, Income, Real Estate.
\end{abstract}

\begin{abstract}
One of the main problems in defining strategies for the real estate market (whether in terms of planning and, therefore, in public administration, or whether of a considerably more speculative nature, and therefore, in the private sector) lies in the operator's less than perfect knowledge of the aspects of supply and demand, due to the real estate market's characteristics.

The prerequisite to starting or sustaining virtuous dynamics in territorial development is knowledge of the real estate market, an area that has now been widely studied, in terms of the potential for economic, social and territorial development. This paper proposes the application of a synthetic index, the Housing Affordability Index (HAI), which was developed in detail at the municipality level to identify areas where housing is inadequate. The territorial scope includes Northwest regions of Italy, Liguria and Lombardy. HAI allows to assess (if), localize (where) and measure (how many families) housing situation and need. Secondly, HAI can be a tool to help allocate economic resources more efficiently.
\end{abstract}

\section{Premise and rationale for the research}

One of the main problems in defining strategies for the real estate market ${ }^{1}$ (whether in terms of planning and, therefore, in public administration, or whether of a considerably more speculative nature, and therefore, in the private sector) lies in the operator's less than perfect knowledge [2] of the aspects of supply and demand, due to the real estate market's characteristics [3-4].

In real estate sector, more than others, it's very difficult to rely on models to analyse and forecast [5]. This is due to its complexity and the difficulty in finding the variables, their interactions, and most importantly, the estimate of the "sociological component" that characterizes the consumer in choosing the right real estate and often determines phenomena in which submarkets with different trends (ripple effect) are formed.

In addition, given the unique nature of real estate, the models provide qualitative and quantitative predictions that often make them so general that their meaning is compromised.

An error of judgment in choosing the allocation of resources due to lack of information or poor handling of information, especially when the topic is as sensitive as housing is, can have consequences for local community and territorial development when:

- the allocation of economic resources, even more serious where resources are scarce, is inefficient and ineffective;

- basic needs, such as that of housing, are not met, and this leads to a spreading of so-called social and housing problems [6];

- responding to a need for housing with unsuitable policies (popular housing intended for income brackets that are unable to sustain the housing costs) actually leads to a worsening of

\footnotetext{
${ }^{1}$ Real estate is "property consisting of land and the buildings on it, along with its natural resources such as crops, minerals, or water; immovable property of this nature; an interest vested in this; (also) an item of real property; (more generally) buildings or housing in general. Also: the business of real estate; the profession of buying, selling, or renting land, buildings or housing“" [1]
} 
the housing situation and degradation of property made available by public administration [7-8];

- the area may be affected by two opposing phenomena, but also harbingers of serious spillover effects and social tensions: congestion and depopulation.

The prerequisite to starting or sustaining virtuous dynamics in territorial development is knowledge of the real estate market, an area that has now been widely studied, in terms of the potential for economic, social and territorial development. This paper proposes the application of a synthetic index, the Housing Affordability Index (HAI), which was developed in detail at the municipality level to identify areas where housing is inadequate.

What is housing affordability? "Most fundamentally, it is an expression of the social and material experiences of people, constituted as households, in relation to their individual housing situations"[9]. Access to affordable housing is among the priorities indicated by the 2012 EU Annual Growth Survey [10].

In fact, the updated study [11-12] and the most recent analyses [13] show how, in recent years, the burden of housing costs on Italian family incomes has increased.

The territorial scope includes the Northwest regions of Italy, Liguria and Lombardy.

To process the HAI data, partial use was made of the methodology from the OMIsE (Observatory on Real Estate Values) of the Internal Revenue and the Bank of Italy's ABI Bureau of Economic Analysis.

It uses methods that are similar to those used by the American National Association of Realtors $(\mathrm{NAR})^{2}$. These are then adapted to the Italian market, the financial cost associated with the amortization of a loan of $\mathrm{T}$ duration and the loan-to-value, LTV\% necessary to cover the costs of buying a home. Usually these parameters are placed respectively at 20 years and $80 \%$.

Given that a burden equal to $30 \%$ of a family's disposable income is considered sustainable ${ }^{3}$ for the purchase of a house, the HAI is calculated as the difference between the threshold value of $30 \%$ and the incidence of the installment, following the signing of the mortgage loan.

The formula is:

$$
\mathrm{HAI}=30 \%-\frac{\text { payment }(\mathrm{i}, \mathrm{T}, \text { price } \mathrm{x} \mathrm{LTV} \%)}{\text { income }}
$$

where:

payment: mortgage payment (for month), depending on interest rate $\mathrm{i}$, mortgage duration $\mathrm{T}$ and loan to value LTV

income: monthly family's available income ${ }^{4}$

Positive index values indicate that the average family living in a given territory is able to buy the house at the average market price, and vice versa, negative values indicate that the family is not able to purchase or can do so only within the lowest price category.

For example, if the average family's income is $2,400 €$ and the average mortgage payment is $900 €, \mathrm{HAI}$ is equal to:

$$
\mathrm{HAI}=30 \%-\frac{€ 900}{€ 2,400}=-8 \%
$$

\footnotetext{
${ }^{2}$ According to the Nar definition, "This quarterly report measures the ability of a family earning the median income to purchase a median-priced home".

${ }^{3}$ Assumption is for a $30 \%$ "housing exp/net income" ratio to be sustainable, even if the ratio may vary in relation to income level: "The average household devotes roughly one-quarter of income to housing expenditures, while poor and near-poor households commonly devote half of their incomes to housing" [14].

"For this study HAI is calculated by "mean income" and "mean price". Other authors refer to "median income" and "median price" [15-16]. An adjustment in calculating HAI, at national level, based on "median income" was performed in Italy, by Ministero del Lavoro e delle Politiche Sociali [17].
} 
It means that the average family is not able to buy the house at the average market price.

Of course, the positive (negative) distance from the value of 0 represents greater ease (or difficulty) in buying a house for a family residing in a particular territory.

Currently, as noted above, the HAI data is processed by OMIsE (Observatory on Real Estate Values) of the Internal Revenue Agency in collaboration with the ABI Bureau of Economic Analysis [18]. The data is available from the first half of 2004 until the second half of 2012, at the local macro area (North, Central, South), regional and national level.

\section{Calculation of the HAI for municipalities and homogeneous areas}

The HAI was calculated at the municipal level (for the 1,545 municipalities of Lombardy and the 235 municipalities of Liguria), by creating a dedicated database in Excel environment, and focusing on the aforementioned variables: purchase price, income, interest rate on mortgage loans.

With regard to the average market price, recent data is only available for the main cities [19].

For other municipalities, in the absence of data, the estimate was made by using the indicator "Level of real estate prices by territory" (real estate listing), set out in Schedule 1 of the Supplement to the Official Gazette, Extraordinary Issue No. 16 of December 31, 2012. This indicator, between 0 and 1 , makes it possible to differentiate areas in the national territory on the basis of the market values of properties by Province, Region and local areas.

Liguria and Lombardy belong to the North West macro area, which has a real estate listing equal to 0.2091 .

However, Liguria has a higher real estate listing, not only in the macro area, but compared to the rest of Italy (with a value of 0.3712 , followed by Lazio, with 0.3471 ); Lombardy has a value of 0.1893 .

At the provincial level, Genoa has a real estate listing value equal to 0.3812 (in Italy second only to Rome: 0.4328 ), compared to a value equal to 0.2603 in the province of Milan.

In Liguria, in addition to the municipality with the 1 indicator (Portofino ${ }^{5}$ ), there are 50 municipalities $(21.3 \%$ of the total of municipalities and nearly $11 \%$ of the population) with real estate listings between 0.50 and 1 .

Another 83 (accounting for nearly $60 \%$ of the population) have a very high real estate listing (between 0.30 and 0.50): the regional capital and Imperia belong to this cluster.

The other two main cities (La Spezia and Savona) have a real estate listing between 0.20 and 0.30 .

In terms of the number of municipalities and the resident population, there remain the categories with a real estate listing of less than 0.10 .

\footnotetext{
${ }^{5}$ There are only 3 municipalities with a real estate listing value equal to 1 in Italy: Portofino, Capri and Anacapri.
} 
Table 1 - Clustering of the Municipalities of Liguria and the location of the main cities on the basis of the real estate listings

\begin{tabular}{|c|c|c|c|c|c|}
\hline $\begin{array}{l}\text { Range of variation } \\
\text { Real Estate Listings }\end{array}$ & $\begin{array}{c}\text { No. } \\
\text { cities }\end{array}$ & $\%$ & Main cities & Population & $\%$ \\
\hline $0-0.10$ & 23 & $9.8 \%$ & & 35,549 & $2.3 \%$ \\
\hline $0.10-0.20$ & 40 & $17.0 \%$ & & 192,139 & $12.3 \%$ \\
\hline $0.20-0.30$ & 39 & $16.6 \%$ & La Spezia, Savona & 252,719 & $16.1 \%$ \\
\hline $0.30-0.50$ & 83 & $35.3 \%$ & Genova, Imperia & 916,712 & $58.6 \%$ \\
\hline $0.50-1$ & 50 & $21.3 \%$ & & 168,008 & $10.7 \%$ \\
\hline Total & 235 & $100 \%$ & & $1,565,127$ & $100 \%$ \\
\hline
\end{tabular}

In Lombardy, the municipality with the highest real estate listing is Livigno, with a value of 0.5920 . Falling into the cluster of "over 0.50 " are just 3 municipalities ( $0.1 \%$ of the population).

The capital of the region lies in the " $0.3-0.5$ " category, together with 4 other municipalities, for a total of approximately $1,200,000$ residents ( $13 \%$ of the regional population).

The most represented class (in terms of number of municipalities and resident population) is that with the real estate listing of between 0.10 and 0.20 (respectively $62 \%$ and $61 \%$ of the total).

The category with a real estate listing of less than 0.10 is also very numerous: 508 municipalities, representing more than $1,000,000$ residents (more than $10 \%$ of Lombardy's total).

Table 2 - Clustering in the Municipalities of Lombardy and the location of the main cities on the basis of the real estate listings

\begin{tabular}{|c|c|c|c|c|c|}
\hline $\begin{array}{l}\text { Range of variation } \\
\text { Real Estate Listings }\end{array}$ & $\begin{array}{l}\text { No. } \\
\text { cities }\end{array}$ & $\%$ & Main cities & Population & $\%$ \\
\hline $0-0.10$ & 508 & $32.9 \%$ & & $1,050,247$ & $10.7 \%$ \\
\hline $0.10-0.20$ & 960 & $62.1 \%$ & $\begin{array}{l}\text { Cremona, Mantova, Sondrio, Pavia, } \\
\text { Varese }\end{array}$ & $5,992,997$ & $61.2 \%$ \\
\hline $0.20-0.30$ & 69 & $4.5 \%$ & $\begin{array}{c}\text { Bergamo, Brescia, Lecco, Monza, } \\
\text { Como, Lodi }\end{array}$ & $1,465,121$ & $15.0 \%$ \\
\hline $0.30-0.50$ & 5 & $0.3 \%$ & Milano & $1,275,567$ & $13.0 \%$ \\
\hline $0.50-0.5920$ & 3 & $0.2 \%$ & & 10,593 & $0.1 \%$ \\
\hline Total & 1,545 & $100 \%$ & & $9,794,525$ & \\
\hline
\end{tabular}

Milan and 6 main cities in the province have a relatively high real estate value, while the other five clusters fall into a lower category.

To estimate the average sale value, the municipalities with the highest indicators were: respectively, Portofino for Liguria (indicator equal to 1) and Livigno for Lombardy (indicator equal to 0.5920$)$.

For these municipalities, an examination of OMIsE data was made, concerning real estate listings ("Residential buildings" category for the first half of 2013), showing the minimum and maximum unit values. The average value was not calculated as an arithmetic average, but according to transactions. For other municipalities, the average price was calculated by applying a proportion 
based on the real estate listing indicator and deviation from the reference data. The prices related to the provincial capitals are up to date.

Income data was made available by the Ministry of Economy and Finance, at the municipality level, for the year 2010 [20].

In addition to total income and the number of taxpayers, for each municipality and income bracket, the number of contributors and the amount of revenue is indicated. It is so possible to estimate the average income per taxpayer and the distribution of wealth among the population.

The average income per taxpayer is equal, in Liguria, to €23,810. In Lombardy, it is equal to $€ 25,823$ (which matches the highest value in Italy).

In Lombardy, 149 out of 1,545 municipalities (equivalent to about 10\%) have an income value per taxpayer higher than the regional average, covering $34 \%$ of the total regional population. The absolute value varies between $€ 74,744$ (Municipality of Galliate Lombardo, in the Province of Varese) and the value of $€ 12,400$ (Municipality of Cavargna, in the Province of Como).

In Liguria, 27 municipalities out of 235 (around 11\%) have a value of income per taxpayer higher than the regional average. In these municipalities, we find $55 \%$ of the total regional population.

The absolute value varies between $€ 35,666$ (Pieve Ligure, in the Province of Genoa) and the value of $€ 14,948$ (Municipality of Carpasio, in the Province of Imperia).

For each municipality, estimates were made of the average household income and the amount of the mortgage payment on the house, which supplied all the factors need for the HAI equation.

For the APR (Annual Percentage Rate) 4.03\% was applied.

By applying the formula, the HAI for the municipality and the region is calculated.

\section{Homogeneous areas according the HAI}

The GIS return (Geographical Information System) on the HAI information and data and some basic estimates to calculate it, making it possible to cluster the municipalities and identifying homogeneous areas in terms of accessibility to housing.

In Liguria, the HAI varies between $-64 \%$ (Portofino) and Fascia (GE): $+27 \%$.

In detail, the HAI is negative in 65 out of 235 municipalities ( $28 \%$ of the total, equal to $31.4 \%$ of the population), barely positive ( $<0.5 \%$ in 4 municipalities, $38 \%$ of the resident population).

This reveals clearly some homogeneous areas:

- area along the coast, characterized by a markedly negative HAI (with the exception of La Spezia), where for the average family housing is inaccessible, especially in the two Eastern and Western Rivieras;

- area immediately inland, which is the only area in Liguria with a positive demographic balance, and that begins to show areas with a negative HAI, due to saturation of the available space;

- inner area, characterized by a definitely positive HAI, but made sterile by depopulation and isolated infrastructures. 


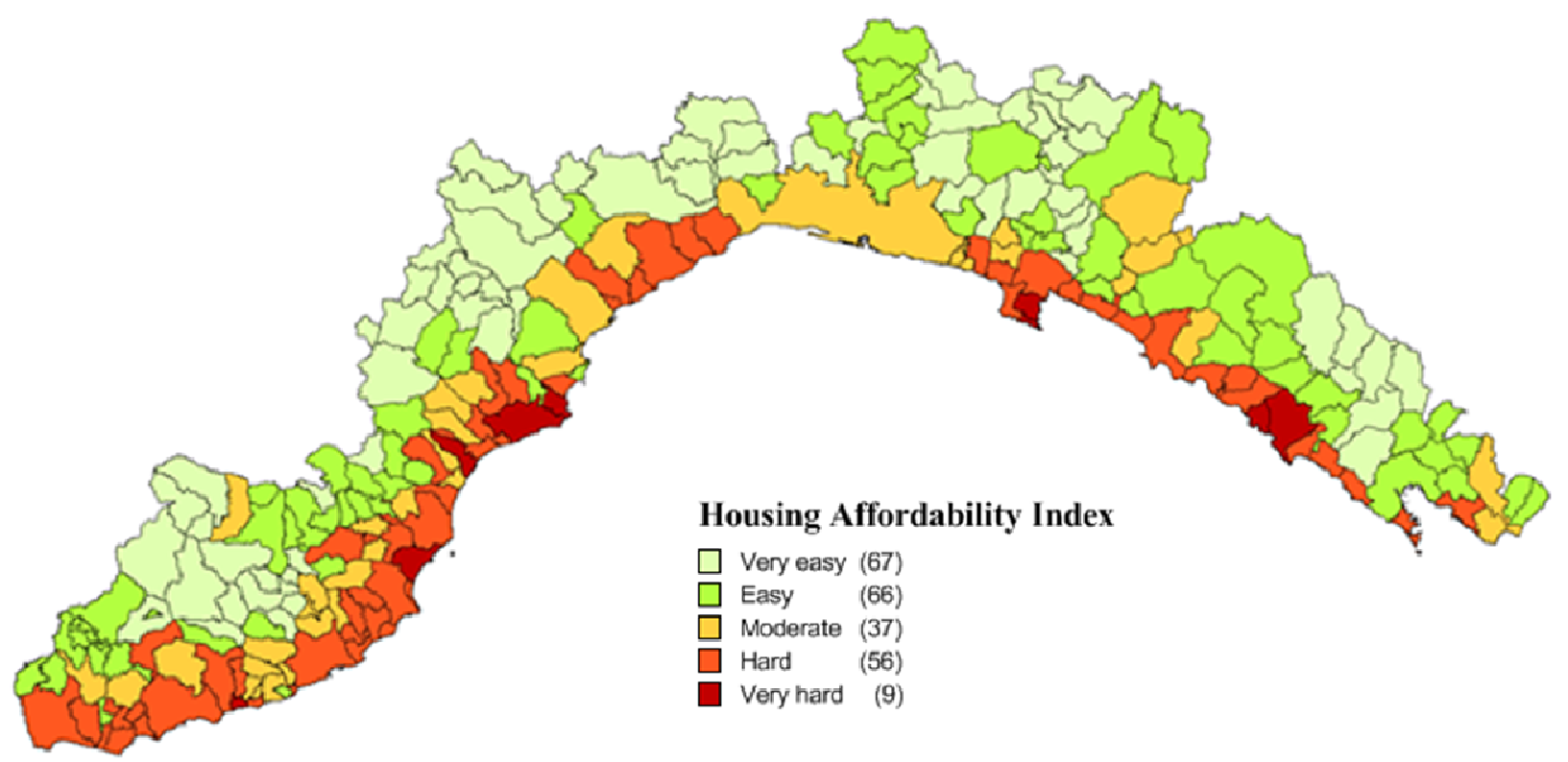

Fig.1 Liguria Region. Homogeneous areas in terms of accessibility to housing

The 10 municipalities in which access to housing is more difficult for the average family are on the left, while the HAI value for the main cities is on the right.

Table 3 - Liguria Region. 10 municipalities in which access to housing is more difficult and HAI value for the main cities

\begin{tabular}{lccllc} 
Municipality & Province & HAI & Main cities & HAI \\
Portofino & GE & $\mathbf{- 6 3 . 9 8 \%}$ & Genova & $\mathbf{0 . 2 9 \%}$ \\
\hline Alassio & SV & $\mathbf{- 5 1 . 7 1 \%}$ & Imperia & $\mathbf{- 1 . 4 9 \%}$ \\
\hline Riva Ligure & IM & $\mathbf{- 2 5 . 7 1 \%}$ & La Spezia & $\mathbf{8 . 9 4 \%}$ \\
\hline Loano & SV & $\mathbf{- 2 5 . 3 5 \%}$ & Savona & $\mathbf{0 . 8 3 \%}$ \\
Bonassola & SP & $\mathbf{- 2 3 . 8 1 \%}$ & & $-7.45 \%$ \\
\hline Santa Margherita Ligure & GE & $\mathbf{- 2 3 . 2 1 \%}$ & Liguria & \\
Levanto & SP & $\mathbf{- 2 1 . 7 7 \%}$ & & \\
Noli & SV & $\mathbf{- 2 1 . 0 9 \%}$ & & \\
Finale Ligure & SV & $\mathbf{- 2 0 . 2 2 \%}$ & & \\
Sestri Levante & GE & $\mathbf{- 1 8 . 0 8 \%}$ & &
\end{tabular}

In Lombardy, the HAI varies between $-25 \%$, in the municipality of Madesimo (SO) and $+25.4 \%$ in the municipality of Galliate Lombardo (VA):

In detail, a negative HAI was recorded in 37 municipalities out of 1,545 (2.4\% of the total, equal to $15.1 \%$ of the population); barely positive ( $<0.5 \%$ in 7 municipalities, including Brescia, equal to $2.1 \%$ of the population).

Some homogeneous areas can be noted:

- tourist areas: the area of Valtellina (municipalities of Livigno, Bormio, Valfurva and Valdidentro, Bormio) in the Valchiavenna (Madesimo) and Valmalenco, Campione d'Italia, 
the tourist area of Lake Garda (Sirmione, specially) with limited access to housing, although this is somewhat less pronounced than in similar tourist areas of Liguria;

- the metropolitan area of Milan, with the capital's sales values that are inaccessible to the average household and the outlying municipalities where housing settlements are possible.

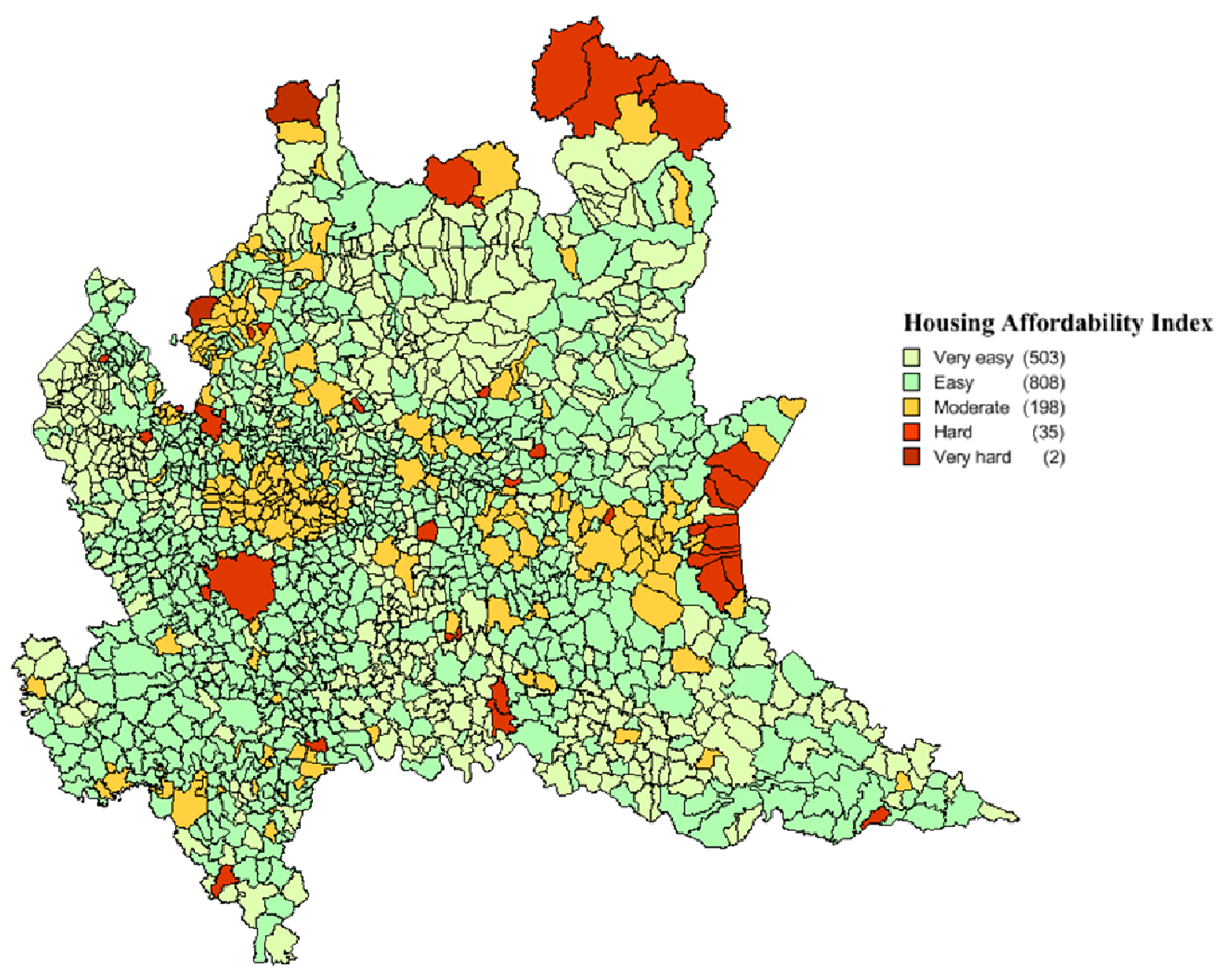

Fig.2 Lombardy Region. Homogeneous areas in terms of accessibility to housing

The 10 municipalities in which access to housing is more difficult for the average family are on the left while the HAI value for the main cities is on the right. 
Table 4 - Lombardy Region. 10 municipalities in which access to housing is more difficult and HAI value for the main cities

\begin{tabular}{|c|c|c|c|c|}
\hline Municipality & Province & HAI & Main cities & HAI \\
\hline Madesimo & $\mathrm{SO}$ & $-24.80 \%$ & Milano & $-1.93 \%$ \\
\hline Valsolda & $\mathrm{CO}$ & $-20.68 \%$ & Brescia & $0.06 \%$ \\
\hline Bormio & $\mathrm{SO}$ & $-19.42 \%$ & Monza & $5.60 \%$ \\
\hline Livigno & $\mathrm{SO}$ & $-19.00 \%$ & Bergamo & $6.14 \%$ \\
\hline Salvirola & $\mathrm{CR}$ & $-15.56 \%$ & Como & $-2.01 \%$ \\
\hline San Giacomo delle Segnate & $\mathrm{MN}$ & $-12.99 \%$ & Varese & $11.85 \%$ \\
\hline Gardone Riviera & BS & $-10.76 \%$ & Cremona & $12.43 \%$ \\
\hline Sirmione & $\mathrm{BS}$ & $-10.23 \%$ & Pavia & $9.41 \%$ \\
\hline Ponte Nossa /Ronago & $\mathrm{BG}-\mathrm{CO}$ & $-9.82 \%$ & Lecco & $5.22 \%$ \\
\hline \multirow[t]{4}{*}{ Manerba del Garda } & $\mathrm{BS}$ & $-8.24 \%$ & Mantova & $14.09 \%$ \\
\hline & & & Lodi & $11.47 \%$ \\
\hline & & & Sondrio & $11.30 \%$ \\
\hline & & & Lombardia & $6.03 \%$ \\
\hline
\end{tabular}

Applying the HAI in 2 regions of the North West makes it possible to highlight some issues.

The homogeneous areas, in terms of equal opportunity (or lack of opportunity) in access to housing, rarely show boundaries that coincide with municipal boundaries. Foremost, consider the whole Ligurian coast, which constitutes a continuum characterized by a substantial inaccessibility to housing for the average family ${ }^{6}$.

These areas have a different configuration [21], depending on whether or not the attraction is related to employment and/or the provision of related services (consider Milan and its metropolitan area, but also smaller centres, such as Como and Brescia) or tourism/climate (consider the Ligurian coast, but also the whole area of Lake Garda and Valtellina). Around a core with a very specific vocation, lack of access to housing drops, moving away from it, allowing for a buffer zone with gradually decreasing index; in the case of areas that attract for their tourism/climate, the area will look more uniform.

Housing policies cannot be made only at the municipal level missing a broader coordination on a regional scale that takes into account the homogenous areas and factors (economic, infrastructural and social) that determine the boundaries of these areas.

The value of the HAI (and not only the real estate market trend) becomes an element that needs to be monitored in order to assess the effects of a plan (urban planning, transport, commercial, goods, traffic, etc...). This is a synthetic indicator [22] that represents what happened and it must then be understood conducing multi-disciplinary examinations, intended to explain why it happened.

HAI allows to assess (if), localize (where) and measure (how many families) housing situation and need. Secondly, HAI can be a tool to help allocate economic resources more efficiently.

Dealing with housing policies, Municipalities with high negative HAI (where an average family can't actually buy its home) could effectively get an agreement with its neighboroughs, to build low cost houses in the most convenient sites, for a sustainable development. For example, funding needed to build social houses in a high priced market such as Portofino, could be spent in much better way to build more houses if they could be built outside municipality boundaries. Such move could be completed by improving the local public transport network, designed to link the areas with the highest HAI spread, up to a regional level.

\footnotetext{
${ }^{6}$ In this regard, it should be noted that the Region of Liguria, at the regional level, has had a continuously negative HAI since 2005 (see fig. 58 of the Real Estate Report 2013), making it unique among the regions of Northern Italy.
} 


\section{References}

[1] Oxford English Dictionary online: Retrieved September 18 (2011)

[2] F. Delbono, S. Zamagni: Microeconomia, Il Mulino, Bologna (1997)

[3] R. Curto: Città e valori. Mercati e presenze dell'economia a Torino, CELID, Torino (1989)

[4] E. Mollica: L'analisi del mercato nella procedura di stima, "Genio rurale" $\mathrm{n}^{\circ}$ 5, Ed. agricole (1994)

[5] V. Del Giudice, M. D’Amato: Principi metodologici per la costruzione di indici dei prezzi nel mercato immobiliare, Maggioli Editore, Rimini (2008)

[6] A. Bardhan, R. Edelstein, C. Kroll, K. Series: Global housing markets: crisis, policies and institutions, in Finance, John Wiley \& Sons inc., New Jersey (2012)

[7] P. Balchin, M. Rhoden: Housing: the essential foundations, Routledge, London (2003)

[8] G. D'Alessio, R. Gambacorta: L'accesso all'abitazione di residenza in Italia, Banca d'Italia, Occasional papers 9, Roma (2007)

[9] M. E. Stone: The Case for the Residual Income Approach, Housing policy debate, volume 17 issue 1, Fannie Mae Foundation (2006)

[10] European Social Housing Observatory, Housing Affordability in the UE, Current situation and recent trend, Year 5, number 1 January 2012

[11] L. Ingaramo, S. Sabatino: Housing Affordability in Italy, ISA, International Housing Conference, Glasgow (2009)

[12] S. Giaccaria, A. Talarico, M. Bravi: Housing Affordability and tenure choices: an empirical investigation, Università di Torino (2008)

[13] ISTAT, I consumi delle famiglie, anno 20125 July 2013

[14] J. Quigley and S. Raphael: Is housing unaffordable? Why isn't it more affordable?, Journal of Economic Perspectives vol. 18, AEA Publications (2004) pp. 191-214

[15] N. Frumkim: Guide to economics indicator, Sharpe inc., New York (2006), p. 128

[16] D. MacKenzie, R. Betts, C. Jensen: Essentials of Real Estate Economics, Cengage Learning, Andover (2011), p. 237

[17] M. Baldini, M. Federici, T. Poggio: Le condizioni abitative delle famiglie italiane in: M. Baldini, Le politiche sociali per la casa in Italia, Quaderni della ricerca sociale n. 22, Ministero del Lavoro e delle Politiche Sociali, Roma (2009) p. 23

[18] Ufficio Statistiche e Studi della Direzione Centrale dell'Osservatorio Mercato Immobiliare e Servizi Estimativi, Rapporto Immobiliare del 2013 (May 2013), pp. 63-84

[19] Osservatorio del Mercato immobiliare, Note territoriali 2013 Genova e Milano, November 2013

[20] Information on http:// www.comuni-italiani.it/statistiche/

[21] R. Camagni: Economia Urbana, Roma, NIS (1992)

[22] P. Castagnino, L. Sdino: Valori immobiliari e politiche per la mobilità: presupposti teorici e rilevanze empiriche, in E. Musso, C. Burlando, H. Ghiara, La città logistica, Il Mulino, Genova (2007), pgg. 303-355 